SHORT COMMUNICATION

Sokoto Journal of Veterinary Sciences

http://dx.doi.org/10.4314/sokjvs.v16i4.10

Abah et al./Sokoto Journal of Veterinary Sciences, 16(4): 79 - 82.

\title{
Elemental analysis and antimicrobial assay of aqueous leaf extract of Celtis integrifolia Lam.
}

\author{
KO Abah ${ }^{1,2 *}$, MB Mahre ${ }^{1} \&$ PP Mshelbwala ${ }^{1,3}$ \\ 5. Department of Veterinary Physiology and Biochemistry, Faculty of Veterinary Medicine, University of Maiduguri, PMB 1069, \\ Borno State, Nigeria \\ 6. Department of Theriogenology, Faculty of Veterinary Medicine, University of Abuja, PMB 117, Abuja, Nigeria \\ 7. Department of Veterinary Medicine, Faculty of Veterinary Medicine, University of Abuja, PMB 117, Abuja, Nigeria
}

*Correspondence: Tel.: +2348130713730; E-mail: kennethabah34@yahoo.com

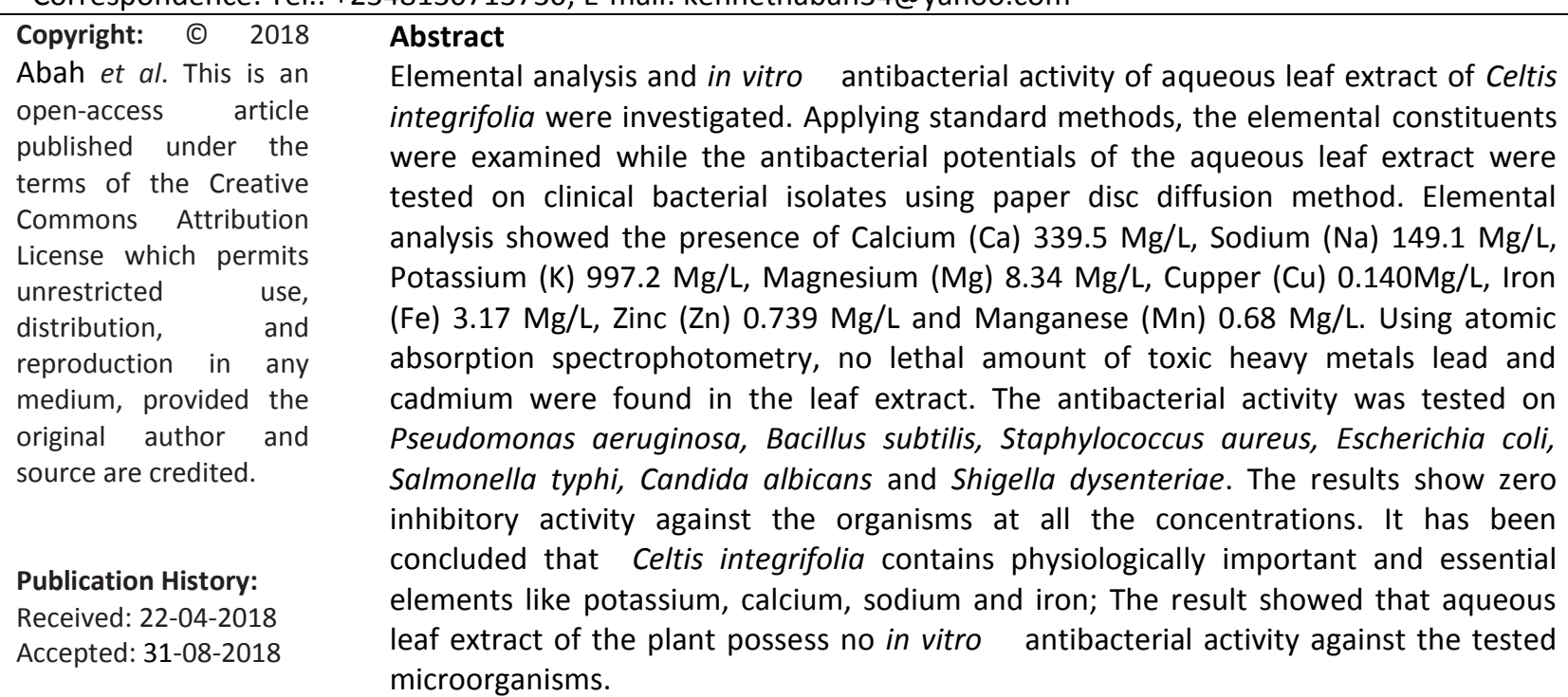

Keywords: Antimicrobial, Aqueous leaf extract, Celtis integrifolia, Elemental analysis, Inhibitory activity

\section{Introduction}

Celtis integrifolia Lam is commonly known as hackberry or nettle tree. In Nigeria, it is called zuwo, nguzo and wanco in Hausa, Kanuri and Fulfulde languages respectively (Burkill, 1985). It grows to a height of about 26 meters. The leaves are alternate, simple, and $3-15 \mathrm{~cm}$ long, ovate and have evenly serrated margins (Herbert, 2004). The leaves, root, stem bark and flower are used in the treatment of epilepsy, measles, small pox, chicken pox, gout and control of diarrhoea by locals in some parts of Nigeria (Burkill, 1985). The leaves of C. Integrifolia are used for various soup preparations in some parts of northern Nigeria (Matawalli et al., 2014).
Plants are used medicinally and can be a potent source of many drugs (Burkill, 1985). The world health organization (WHO) estimated that $80 \%$ of people worldwide rely on herbal medicines for some part of their primary health care and there are reports on natural substances of plant origin which are biologically active with desirable antimicrobial properties (Mahre et al., 2016). It has been established that medicinal plants are a source of compounds with the potential to act against virulent microbes (Burkill, 1985). The aim of this study therefore is to evaluate the elemental composition 
and antibacterial potential of aqueous leaf extract of Celtis integrifolia.

\section{Materials and Methods \\ Collection and preparation of the plant material} Fresh leaves of Celtis integrifolia were collected and authenticated at the Department of Biological Science, University of Maiduguri and a Voucher specimen (Species Vet. 208 A) was deposited the Department of Veterinary Physiology, Pharmacology and Biochemistry herbarium, University of Maiduguri. The leaves were cut into pieces and air dried in the laboratory under room temperature for seven days. The dried samples were grounded into powder using pestle and mortar.

\section{Extraction of plant material}

The powdered sample was exhaustively extracted with water using reflux method. Six hundred grams of the powder was put into the flask and processed according to procedure described by Akinyemi et al. (2005).

\section{Elemental analysis}

Acid digested plant extracts were subjected to Flans Emission spectroscopy (Gallenkanp FGA 330) to determine the presence and concentration of sodium and potassium. Magnesium, cadmium, calcium, iron, lead, zinc, manganese, arsenic, phosporus and copper presence and concentration were determined using atomic absorption spectrophotometry (AAS) (Philip/pye Unicom Ltd, England). The elemental concentrations were determined by a standard calibration curve method (Kolthoff \& Elving, 1976).

\section{Antimicrobial screening}

Source of the bacterial organisms: The stock cultures of the organisms were obtained from the University of Maiduguri teaching hospital. The test organisms were Pseudomonas aeruginosa, Bacillus subtilis, Staphylococcus aureus, Escherichia coli, Salmonella typhi, Candida albicans and Shigella dysenteriae

Preparation of media:

Nutrient Agar was used for sub culture of $\mathrm{S}$. dysenteriae, B. subtilis and S. typhi, Mannitol salt Agar for S. aureus, Eosin methylene blue Agar for $E$. coli, brilliant green agar for $P$. Aeruginosa and Sabourauds dextrose agar for $C$. albicans.

Culture and identification of the organisms: Stock cultures of the organisms were inoculated onto the plates containing the various media. Each organism was put in to a specific media. The plates inoculated were then incubated immediately for 24 hours at $370^{\circ}$, the growths were then identified using colonial appearance, Gram staining, examination of the organisms under microscope, and the use of subculture using different media for confirmation of the organisms identified.

Preparation of stock solution of extracts: Stock solution of extracts was prepared by dissolving $0.01 \mathrm{~g}, 0.02 \mathrm{~g}, 0.03 \mathrm{~g}$ and $0.05 \mathrm{~g}$ of the extract in $1 \mathrm{~mL}$ sterile distilled water to give $100 \mathrm{mg} / \mathrm{mL}, 200 \mathrm{mg} / \mathrm{mL}$, $300 \mathrm{mg} / \mathrm{mL}$ and $500 \mathrm{mg} / \mathrm{mL}$ respectively. An antibiotic of interest, oxytetracycline, at a concentration of $250 \mathrm{mg} / \mathrm{mL}$ was also used on all the bacterial organisms and the zone of inhibition compared with those of the plant extract.

In vitro antimicrobial sensitivity test: Paper disc diffusion method as described by Kirby et al (Kirby et al., 1966) was used to determine the antimicrobial activity of the test extracts. Discs containing different concentrations of dissolved extract were prepared. An overnight culture of each bacterial isolate was spread on the surface of dried nutrient agar plates. The plates were incubated at $37^{c}$ for 30 minutes before the discs were applied aseptically. The treated plates were incubated at $37^{\circ}$ for 48 hours after which they were inspected for the zones of inhibitions using a transparent meter rule. The zones of inhibition were measured and recorded in millimeters $(\mathrm{mm})$. The same procedure was carried out with the oxytetracycline $(250 \mathrm{mg} / \mathrm{mL})$ as control.

\section{Results and Discussion}

The result of the elemental analysis of the leaf extract of $\mathrm{C}$. integrifolia showed a concentration of potassium ions (997.2 Mg/L), calcium (339.5 Mg/L), sodium (149.1Mg/L), Iron (3.17 Mg/L), Magnesium (8.34 Mg/L), copper ( $0.140 \mathrm{Mg} / \mathrm{L})$ manganese (0.6 $\mathrm{Mg} / \mathrm{L})$, lead (0.042 Mg/L), cadmium (0.001 Mg/L) and arsenic (0.125 Mg/L) (Table 1$)$.

The Potassium content was $997.2 \mathrm{Mg} / \mathrm{L}$. This value is higher than that of Acalypha wilkesiana (390 Mg/L) (Madziga et al., 2013). Iron content of the sample was $3.17 \mathrm{Mg} / \mathrm{L}$; which is an appreciable amount. This is lower than Acalypha wilkesiana (9.67 Mg/L). As potassium plays a key role in sodium-potassium pump and iron is an integral structural part of haemoglobin and other non-heme proteins, this plant can serve as a supplementary source of these nutritional elements in human diet.

Sodium content of the sample $(149.1 \mathrm{Mg} / \mathrm{L})$ was low compared to some common Nigerian vegetables (Madziga et al., 2013). Zinc, iron and manganese are 
Table 1: Elemental concentration of $\mathrm{C}$. integrifolia leaf extract

\begin{tabular}{ccc}
\hline Elements & Concentration $\mathrm{Mg} / \mathrm{L}$ & WHO standard Concentration $\mathrm{Mg} / \mathrm{L}$ \\
\hline Calcium (Ca) & 339.5 & $360-800$ \\
Copper (Cu) & 0.140 & $1-3$ \\
Arsenic (As) & 0.125 & - \\
Potassium (K) & 997.2 & $0.1-1.0$ \\
Manganese (Mn) & 0.68 & $10-20$ \\
Lead (Pb) & 0.042 & $1-2$ \\
Cadmium (Cd) & 0.001 & $10-35$ \\
Zinc (Zn) & 0.739 & $15-50$ \\
Magnesium (Mg) & 8.34 & - \\
Iron (Fe) & 3.17 & $0.5-50$ \\
Sodium (Na) & 149.1 & $4-5$ \\
\hline
\end{tabular}

Table 2: In vitro antibacterial activity of aqueous leaf extract of Celtis integrifolia

\begin{tabular}{|c|c|c|c|c|c|c|}
\hline \multirow[t]{2}{*}{ Concentration } & & & & \multicolumn{3}{|c|}{ Zone of Inhibition } \\
\hline & S. aureus & S. pyogenes & E. coli & P. aeruginosa & B. Subtilis & S. typhii \\
\hline $100 \mathrm{mg} / \mathrm{mL}$ & & & & & & \\
\hline $200 \mathrm{mg} / \mathrm{mL}$ & & & & & & \\
\hline $300 \mathrm{mg} / \mathrm{mL}$ & & & & & & \\
\hline $500 \mathrm{mg} / \mathrm{mL}$ & & & & & & \\
\hline Oxytetracycline $(250 \mathrm{mg} / \mathrm{mL})$ & $25 \mathrm{~mm}$ & $28 \mathrm{~mm}$ & $22 \mathrm{~mm}$ & $20 \mathrm{~mm}$ & $22 \mathrm{~mm}$ & $25 \mathrm{~mm}$ \\
\hline
\end{tabular}

dietary trace elements needed for a healthy immune system among other functions. They were all present in appreciable amounts in the plant studied. Calcium content in the plant is reasonably high compared to Acalypha wilkesiana (30.89Mg/L) and Cassia arereh (105.6 Mg/L) (Olusola et al., 2011). Since the daily requirement of $\mathrm{Ca}$ is $1.2 \mathrm{~g}$ until the age of twenty four, Celtis integrifolia should not be taken in large amounts because excess calcium has a negative effect on the heart (Sceriano et al., 1995). Excess calcium may lead to respiratory and cardiac failure (Dukes, 1984). Magnesium content of C. Integrifolia was $8.34 \mathrm{Mg} / \mathrm{L}$. this value is higher than Acalypha wilkesiana $(5.41 \mathrm{Mg} / \mathrm{L})$ and lower than Cassia arereh (34.0 Mg/L).

The organisms were found to be resistant to the aqueous leaf extract of Celtis integrifolia at all the four different concentrations. Minimum inhibitory concentration therefore could not be calculated. All the organisms were however susceptible to the control (oxytetracycline, $250 \mathrm{mg} / \mathrm{mL}$ ): S. aureus $25 \mathrm{~mm}$, S. pyogenes $28 \mathrm{~mm}$, E. coli $22 \mathrm{~mm}, \mathrm{P}$. aeruginosa $20 \mathrm{~mm}$, B. Subtilis $22 \mathrm{~mm}$ and S. typhi $25 \mathrm{~mm}$ (Table 2). This result showed that aqueous leaf extract of Celtis integrifolia possess no in vitro antibacterial activity against the tested microorganisms. However, other solvents like methanol, ethanol and ether should be used to prepare the extract. This may produce some inhibitory effect on the bacterial organisms compared to the aqueous extract used in this study. In conclusion, the result obtained in this work revealed the presence of physiologically important and essential elements like potassium, calcium, sodium and iron. The aqueous leaf extract of the plant did not show any inhibitory effect on the tested bacterial organisms. Earlier works reported the presence of saponins, tannins, reducing sugar, flavonoids and cardiac glycosides in the aqueous leaf extract of C. Integrifolia. Some of these chemical substances are shown to have anti-microbial activity against both gram positive and gram negative organisms (Sanni, 2007). However, this result revealed the reason Celtis integrifolia is not reported by traditional medicine users to be effective against diseases of bacterial or fungal origin.

\section{References}

Akinyemi KO, Oladapo O, Okwara CE, lbe CC \& Fasure KA (2005). Screening of crude extracts of six medicinal plants used in South-West Nigerian unorthodox medicine for anti-methicillin resistant Staphylococcus aureus activity. BMC Complementary and Alternative Medicine, 5(1): 6.

Burkill HM (1985). The Useful Plants of West Tropical Africa, Second edition, Royal Botanic Gardens, Kew, United Kingdom. Pp 98-157. 
Dukes (1984). Dukes Veterinary Physiology. Second edition, Wiley-Blackwell, lowa, USA. Pp 305307.

Herbert PND, Penton EH, Burns JM, Janzen DH \& Winnie $H$ (2004). Ten species in one: DNA barcoding reveals cryptic species in the semitropical skipper butterfly Astraptes fulgerator. National Academy of Science, 101(41): 14812-14817.

Kirby E, Bauer AW, Sherris JC \& Turck M (1966). Antibiotic susceptibility testing by a standardized single disc method. American journal of clinical pathology, 45(4): 493-496.

Kolthoff IM \& Elving PJ (1976). Treatise on Analytical Chemistry: Part I, Vol. XV John Wiley and Sons., New York-London-Sydney. Pp 15 100.

Madziga HA, Sanni S \& Sandabe UK (2013). Phytochemical and Elemental Analysis of Acalypha wilkesiana Leaf. Saussurea, 3(1): 34-38.

Mahre MB, Umaru B, Ojo NA, Saidu AS, Yahi D, Ibrahim RM \& Mshelbwala PP (2016). Acute Toxicity, Phytochemistry and Antidiarrheal Effects of Celtis integrifolia Lam. Aqueous Leaf Extract in Wistar Albino Rats.
British Journal of Pharmaceutical Research, 14(5): 1-7.

Matawalli AG \& Ochepo SA (2014). Effects of Aqueous Ethanolic Leaf Extract of Celtis Integrifolia on Liver Function of Wister Strain Albino Rats. International Journal of scientific research and management, 2(4): 713-718.

Olusola A, Olutayo O, Michael A, Olakunle F \& Edah AO (2011). Elemental analysis and Antimicrobial potentials of the leaf extract of Cassia arereh Del. International Research of Pharmacy and Pharmacology, 1(8): 188193.

Sanni S (2007). Pharmacological and Toxicological effects of Olimum Basilicum Linn. Aqueous extract in rats. PhD thesis, Department of Veterinary Physiology and Pharmacology, Faculty of Veterinary Medicine, Usmanu Danfodiyo University Sokoto. Pp 16.

Sceriano JK, Walter EA, Glew RH, Hollis BW, Henry A, Ocheke I \& Ischei CO (1995). Serum levels of the pyridinoline crosslinked carboxyterminal telo peptides of type 1 collagen (ICTP) and Osteocalcin in rachitic children in Nigeria. Clinical Biochemistry, 28(5): 541-545. 